\title{
Loculicytheretta morkhoveni sp. nov. (Ostracoda) from West Africa and its relevance to the history of the Mediterranean Seaway
}

\author{
LEENDERT J. WITTE \\ Geological Institute, University of Amsterdam, Nieuwe Prinsengracht 130, 1018 VZ Amsterdam, Netherlands
}

\begin{abstract}
Loculicytheretta morkhoveni sp. nov., of which the females have six loculi per valve, was found in Recent beachsand samples from Senegal and The Gambia (West Africa). A displaced specimen of the same species was present in a sample from deeper water off Guinea, where it occurred with $L$. aff. $L$. pavonia (having four loculi per valve). The presence of the Mediterranean species $L$. pavonia (with three loculi) in deep samples West of Gibralter is interpreted as a result of transportation by outflowing currents.

The discontinuous distribution pattern of the genus Loculicytheretta is tentatively related to a reversal of the flow regime in the Mediterranean basin during the Pliocene.
\end{abstract}

\section{INTRODUCTION}

The genus Loculicytheretta Ruggieri, 1954 has received relatively much attention from ostracod workers, not only because of its stratigraphical importance, but also because of its morphological peculiarities. The females are in the possession of posteroventral loculi; this feature is common in Palaeozoic Ostracoda but among the post-Palaeozoic Ostracoda only known to occur in the genera Loculicytheretta and Heptaloculites Ruggieri, 1963. The true function of these structures is as yet poorly understood, and various hypotheses have been proposed (McKenzie, 1971; Athersuch \& Bonaduce, 1976).

Until van Morkhoven's (1962/63) extensive review of post-Palaeozoic ostracods was published, only the type species, L. pavonia (Brady, 1866) was known to science. In his treatment of the genus, van Morkhoven reported and illustrated a species from West Africa (The Gambia), quite similar to the type species, but differing in having six instead of three loculi in the female valve. In the present paper, this species is reported from two West African localities, and a formal description is presented.

At this moment a total of 10 species is attributed to the genus Loculicytheretta s.s., ranging in age from Miocene to Recent. The morphologically similar genus Heptaloculites Ruggieri, 1963 includes 12 species, all of which are of Eocene age. Excellent illustrations of numerous species of both genera were given in Bismuth et al. (1978), and the evolution and palaeogeographic distribution was discussed. By these authors, Heptaloculites was treated as a junior synonym of Loculicytheretta and included in the latter. Carbonel \& Colin (1982) demonstrated that the Palaeogene and the Neogene to Recent groups of loculate ostracods, although morphologically similar, belong to separate phylogenetic lineages, and reintroduced Heptaloculites for the Palaeogene species.

This paper forms part of a larger study on West African ostracods. The Loculicytheretta material is deposited in the Geological Museum of the University of Amsterdam, collection nos. K 7530 - K 7540 and K 7550 - K 7556.

\section{RESULTS}

In three samples from the coast of Senegal and The Gambia, a species of Loculicytheretta was found that appeared to be identical to the species van Morkhoven (1962/63) reported from the Subrecent of The Gambia. The samples were taken from the sediment surface at approx. $50 \mathrm{~cm}$ below the low-tide line, from open beach, high energy environments. A volume of about $100 \mathrm{cc}$, consisting of siliceous fine to medium grained sand, was examined. In all samples, very rich ostracod faunas were found; other constituents were shell debris and benthic foraminifera.

The same Loculicytheretta species was found in a sand sample collected at a depth of $133 \mathrm{~m}$ off the coast of Guinea. This sample was the shallowest out of a series of boxcore grabs collected during Geotropex ' 83 ("Meteor" expedition no. 65). The single carapace found in this material has a smooth, polished surface, probably resulting from downslope transport.

This sample also yielded anotner representative of the genus: $L$. aff. L. pavonia (sensu Bismuth et al., 1978), which also had a smooth surface and may also be displaced. The latter form closely resembles Loculicytheretta pavonia (Brady), but is distinguished by having four loculi, one of which is often poorly developed. Bismuth et al. (1978) reported this form from a number of West African localities and a description and 


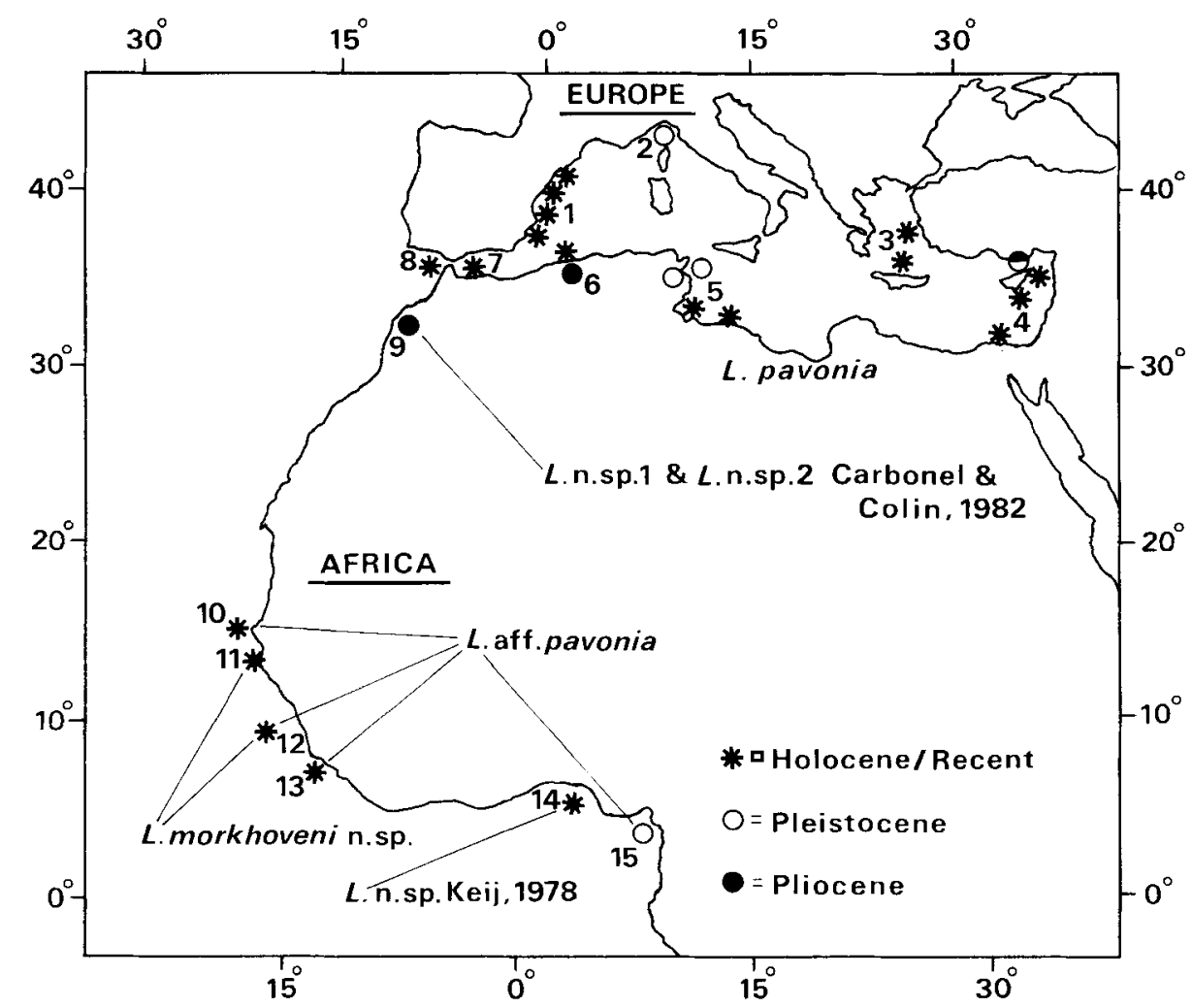

Fig. 1. Distribution of Pliocene to Recent Loculicytheretta (based in part on Bismuth et al., 1978).

Loculicytheretta pavonia (Brady, 1866)

1. Spanish coast, Recent: van Morkhoven, 1962/63; McKenzie, 1973; Doruk, 1974; Athersuch \& Bonaduce, 1976; Bismuth et al., 1978; Carbonel \& Colin, 1982. 2. Ligurian Sea, Pleistocene: Ruggieri, 1954. 3. Aegean Sea, Recent: Brady, 1866; Müller, 1912; Barbeito-Gonzalez, 1971. 4. Eastern Levant, Recent, Plio-Pleistocene: McKenzie, 1973; Doruk, 1974; Athersuch \& Bonaduce, 1976; Athersuch, 1979. 5. Tunisian and Libyan coast, Recent, Plejstocene: Bonaduce \& Masoli, 1968; Puri et al., 1969; Wouters, 1973; Bonaduce \& Pugliese, 1975; Athersuch \& Bonaduce, 1976; Bismuth et al., 1978. 6. Algeria, Recent, Pliocene: Yassini, 1979a, 1979b. 7. Alboran Sea, Recent?: Benson \& Sylvester-Bradley, 1971. 8. Gulf of Cadiz, Recent?: this paper.

Loculicytheretta sp. 1 and L. sp. 2 Carbonel \& Colin, 1982

9. Morocco (precise location not known), Early Pliocene, Pliocene: Carbonel \& Colin, 1982.

Loculicytheretta sp. aff. L. pavonia (Brady, 1866)

10. Senegal (off Dakar), Recent: (?Peypouquet, 1977), Bismuth et al., 1978. 12. Guinea, Recent, this paper. 13. Sierra Leone, Recent: Keen, 1972. 15. Nigeria, Recent, Pleistocene: Bismuth et al., 1978.

Loculicytheretta n. sp. Keij, 1978

14. Nigeria, Recent: Bismuth et al., 1978.

Loculicytheretta morkhoveni sp. nov.

11. South Senegal, The Gambia, Recent, Subrecent: van Morkhoven, 1962/63; this paper. 12. Guinea, Recent: this paper.

discussion of its affinities was given. The suggestion was made by these authors that this form, as well as the form with six loculi, are Pleistocene offshoots of ancestral L. pavonia.

L. pavonia ranges from Pliocene to Recent and is known from a considerable number of localities in the Mediterranean area (Fig. 1). Benson \& SylvesterBradley (1971) reported the species from samples collected in the Alboran Sea at depths of $620 \mathrm{~m}$ and $700 \mathrm{~m}$ as its westernmost occurrence. A new locality that can be added to the list is the Gulf of Cadiz (approx. $12 \mathrm{~km} \mathrm{~W}$. of the Strait of Gibralter), where it was found in three samples collected during a cruise in 1982 with B/O Cornide de Saavedra (Istituto Jaime Almeria, Barcelona).

\section{DISCUSSION}

The presence of L. pavonia in material from the Gulf of Cadiz is the first report of this species from outside 
the Mediterranean. It is, however, obvious that the faunas found in these samples do not represent a biocoenosis. The species was found in three surface samples (upper $2 \mathrm{~cm}$ ), collected at depths of $510 \mathrm{~m}$, $836 \mathrm{~m}$ and $1166 \mathrm{~m}$. The mixed origin of the material can be inferred from the presence of ostracod species characteristic of neritic Mediterranean environments (such as Semicytherura sulcata (G. W. Müller) and Cytheretta adriatica Ruggieri), in combination with other species that are found today only in colder, more northern environments (Finmarchinella angulata (Sars), Cythere lutea O. F. Müller). Bottom currents through the Strait of Gibralter will have picked up material moving downslope, and subsequently transported this over the sill into the Atlantic. It cannot be decided whether such a westward transportation, or a reworking of older sediments, or even a combination of both processes can explain the reported occurrences. But one thing that can be safely assumed is that Loculicytheretta pavonia, being a typical inhabitant of very shallow water (Bismuth et al., 1978), is not able to survive in deeper waters. The present-day Mediterranean watermass circulation is of an anti-estuarine type; surface currents bring in water from the Atlantic, bottom waters leave along the floor of the Strait of Gibralter (Fig. 2). Thus, migration of a strictly shallow water genus out of the Mediterranean as a result of a current pattern as it exists today is unlikely. There is, however, evidence that in the Early Pliocene this circulation pattern was reversed, with a wide and deep connection situated approximately where Gibralter is

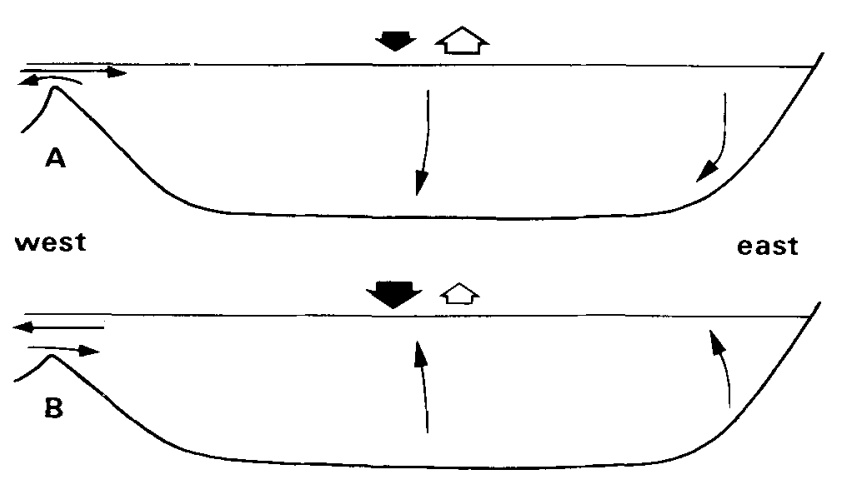

Fig. 2. Mediterranean watermass circulation (after van Harten, 1984). A. Modern type anti-estuarine system: surface currents enter the basin, deep waters leave along the floor of the Strait of Gibralter. B. Estuarine system, model probably applicable until the Late Pliocene: surface currents are directed towards the Atlantic, deep waters flow over the sill into the basin.

Broad arrows symbolise the balance between evaporation (open arrows) and freshwater input (black arrows). now, but extending southward into Morocco and northward into southern Spain. During this period, deep water ostracods could invade the Mediterranean (Benson \& Sylvester-Bradley, 1971; Benson, 1973, 1976; van Harten, 1984). It is considered that at the same time, facilitated by the outflowing surface currents directed towards the Atlantic, shallow water genera, such as Loculicytheretta, could have enlarged their realm to include not only the southern beaches of the Mediterranean, but the adjacent areas in Northwest Africa as well. Subsequent speciation as a result of adaptation to slightly different environments may have given rise to a number of closely related forms, distinguished in particular by the number of loculi.

But where, at the beginning of the Pliocene, did the genus come from? The distribution of the postPalaeozoic loculate ostracods shows considerable gaps, both in a horizontal and in a vertical sense. A total of 22 species is known (Bismuth et al., 1978); six of these are Pliocene to Recent and found along the coasts of West and Northwest Africa and in the Mediterranean. This is the "pavonia" group considered in this paper. A second group, with four species, is restricted to the Miocene of Southwest France, Portugal and North Africa. These two groups together were named group II by Carbonel \& Colin (1982) and these authors suggested for this group an origin different from that of yet another, strictly Eocene group, which is found predominantly in North Africa and includes at least 12 species.

Oligocene species of loculate Ostracoda are not known and this is one reason why Carbonel \& Colin (1982) make a clear distinction between the Palaeogene and Neogene species. For the Palaeogene species group, they proposed to retain the genus Heptaloculites Ruggieri, 1963, whereas the Neogene taxa were allocated to Loculicytheretta Ruggieri, 1954.

Another break in the record of Loculicytheretta can be found between the Late Miocene and Early Pliocene. Although the record of the genus is continuous, no species is known to be present in both periods. The end of the Miocene is marked in the Mediterranean by the Messinian Salinity Crisis, and it seems probable that the break in the Loculicytheretta lineage correlates with this catastrophic event. As suggested by Benson \& Sylvester-Bradley (1971) for deep-water ostracods, the development of new faunas, after refilling of the basin, may have started with forms that invaded the basin or survived in isolated areas. Possibly the shallow water species Loculicytheretta pavonia evolved from such a Miocene survivor. After the end of the Salinity Crisis, immense areas with a suitable habitat were generated, and a rapid occupation of these areas could be effected, followed by the migration of the genus into the Atlantic. Here, from the ancestral Loculicytheretta with three loculi, other 


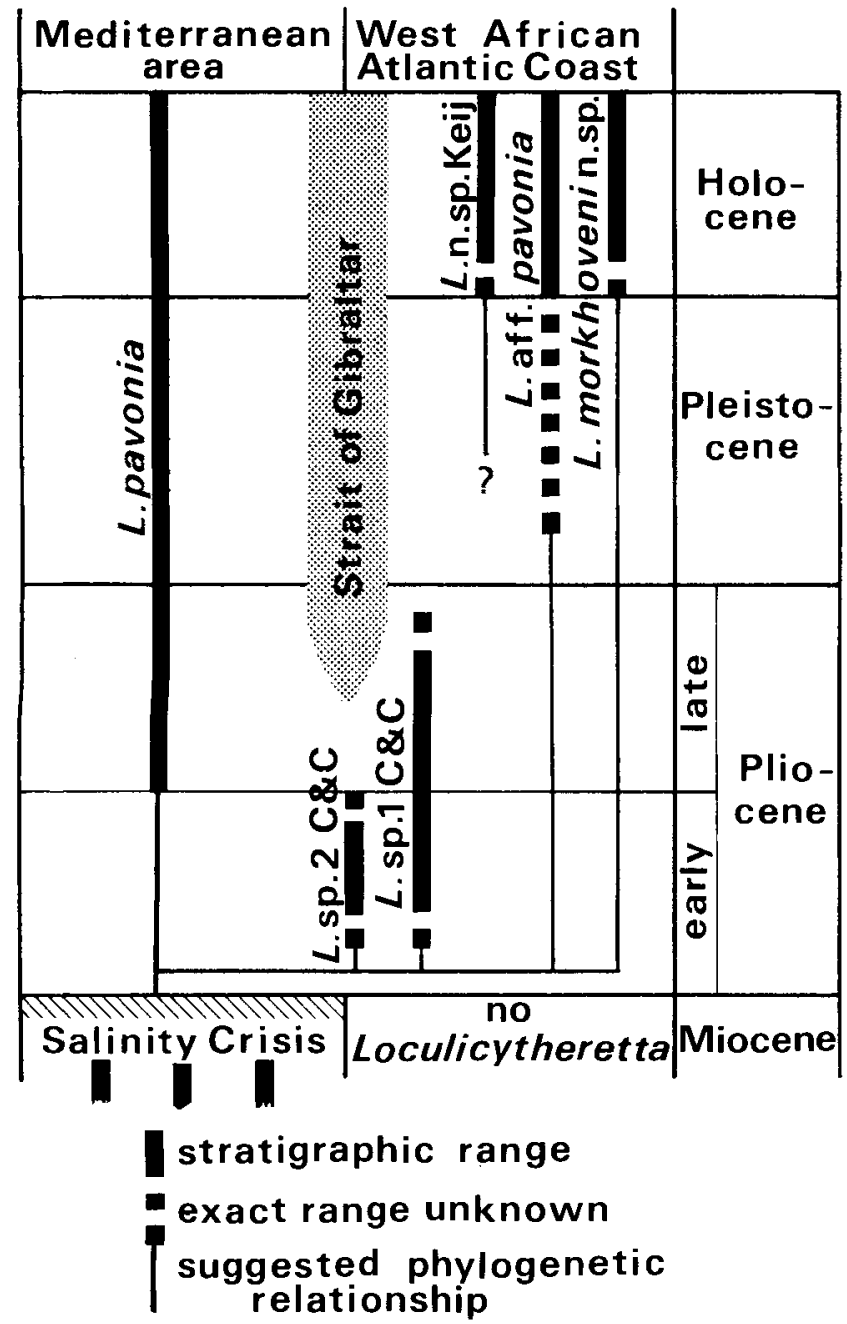

Fig. 3. Schematic representation of the stratigraphic position of post-Miocene Loculicytheretta species and the possible phylogenetic relations.

L. pavonia probably descended from one of the Miocene Mediterranean forms that became extinct as a result of the Salinity Crisis. From the African Atlantic coast no Miocene Loculicytheretta are known.

Since the Late Pliocene reversal of the current system, the Strait of Gibralter acts as a barrier to ocean-directed migration of the shallow water inhabitant $L$. pavonia. taxa evolved, of which most developed more than three loculi (Fig. 3). Pliocene Loculicytheretta are known from the Mediterranean (Doruk, 1974; Yassini, 1979b) as well as Morocco (Carbonel \& Colin, 1982).

We imagine that when in the Late Pliocene the circulation pattern reversed and the wide and deep connection with the Atlantic was reduced to no more than a narrow strait, a wedge was driven in the until then continuous distribution of the genus around northern Africa. This effect was intensified by the drastic climatic changes that followed and Loculicytheretta pavonia became isolated from its Atlantic descendants permanently.

\section{SYSTEMATIC DESCRIPTIONS}

Suborder Podocopina Sars, 1866 Superfamily Cytheroidea Baird, 1850 Family Cytherettidae Triebel, 1952 Subfamily Cytherettinae Triebel, 1952 Tribus Loculicytherettini Gründel, 1976 Genus Loculicytheretta Ruggieri, 1954

Loculicytheretta pavonia (Brady, 1866) (PI. 1, figs. 1, 3)

1866 Cythere pavonia Brady: 378, pl. 61, figs. 2a, b. 1963 Loculicytheretta pavonia (Brady); van Morkhoven: 130-134, figs. 194-200, 202.

1974 Loculicytheretta pavonia (Brady); Doruk: 237244.

1976 Loculicytheretta pavonia (Brady); Athersuch \& Bonaduce: $349-364$, pl. 1-3.

1978 Loculicytheretta pavonia (Brady); Bismuth, Keij, Oertli and Szczechura: 232, pl. 1, figs. 1-11.

1979 Loculicytheretta pavonia (Brady); Yassini (a): 378, pl. 3, figs. 13-15.

1979 Loculicytheretta pavonia (Brady); Yassini (b): 97 , pl. 2, fig. 15 .

1982 Loculicytheretta pavonia (Brady); Carbonel \& Colin: 440-443, pl. 1, figs. 1-9.

\section{Explanation of Plate 1}

Figs. 1, 3. Loculicytheretta pavonia (Brady), 9 RV, K 7552: fig. 1, lateral view $(\times 90)$; fig. 3, ventral view $(\times 82)$. Gulf of Cadiz.

Figs. 2, 5, 6. Loculicytheretta aff. L. pavonia (Brady;, $\&$ car., K 7555: fig. 2, left lateral view ( $\times 90)$; fig. 5, ventral view $(\times 82)$; fig. 6 , right lateral view $(\times 90)$. Offshore Guinea.

Figs. 4, 7-11. Loculicytheretta morkhoveni sp. nov.: fig. 4, $q$ car. $(\times 82), \mathrm{K} 7556$, ventral view; fig. 7, 9 car., $\mathrm{K} 7556$, left lateral view $(\times 90)$; fig. $8, q \mathrm{RV}, \mathrm{K} 7530$ (Holotype), oblique external view $(\times 95)$; fig. 9 , $\$$ car., $\mathrm{K} 7556$,

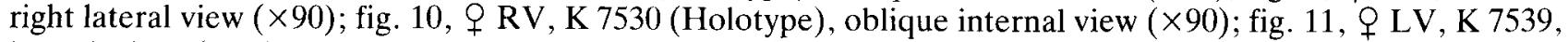
lateral view $(\times 90)$. Specimen K 7556, offshore Guinea; specimens $\mathrm{K} 7530$ and $\mathrm{K} 7539$, type locality. 


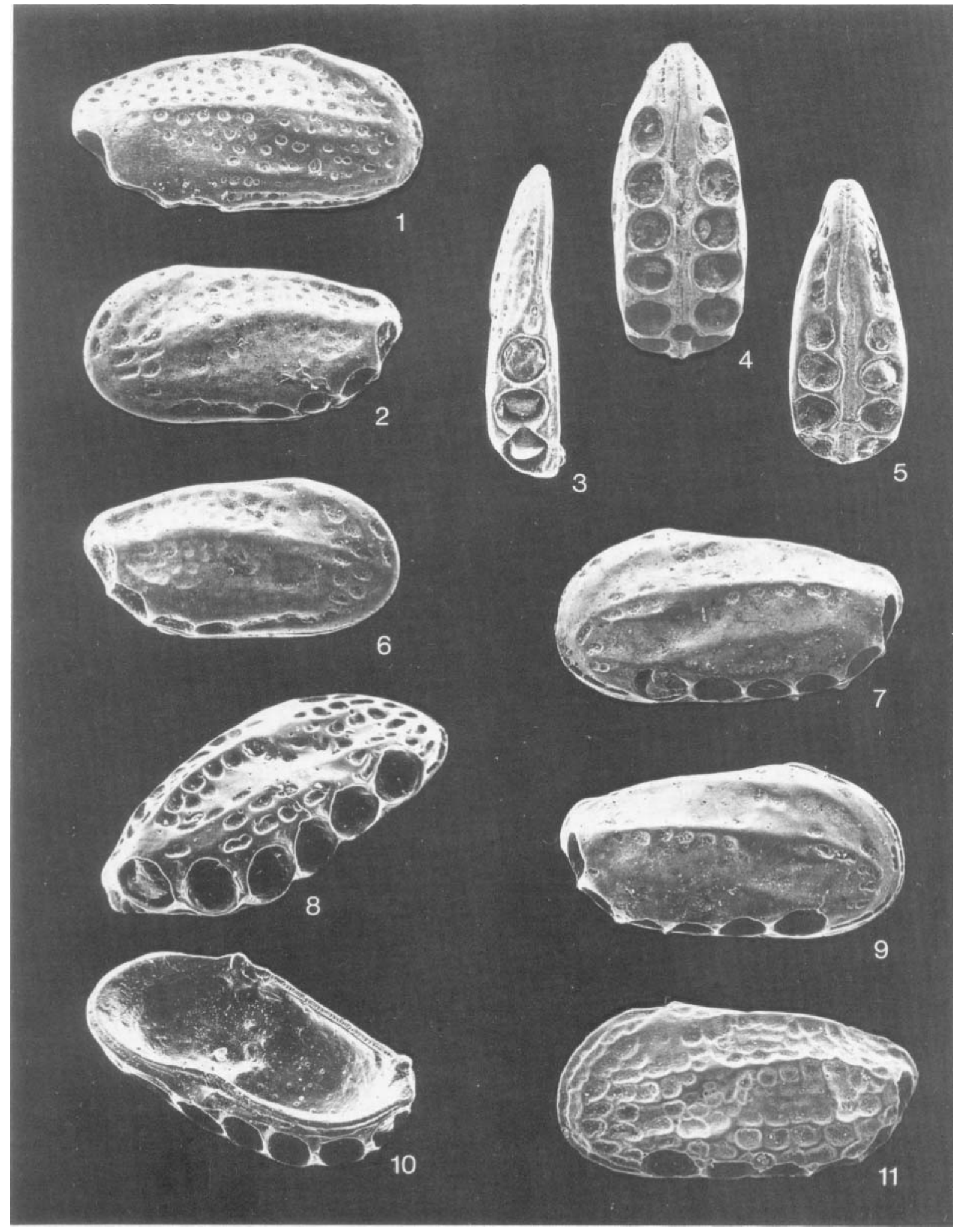


Remarks. The triloculate species Loculicytheretta pavonia is reported from quite a number of Recent localities in the Mediterranean (see Fig. 1 in this paper; Athersuch \& Bonaduce, 1976; Bismuth et al., 1978). Doruk (1974) mentioned its presence in the Plio Pleistocene of Italy and Turkey, and Yassini (1979b) in the Pliocene of Algeria.

The stations in the Gulf of Cadiz where it was found are the following: Station G 127, depth $510 \mathrm{~m}$, lat. $36^{\circ} 10,2^{\prime} \mathrm{N}$, long. $06^{\circ} 41,9^{\prime} \mathrm{W}$ (two female valves); Station $\mathrm{G} 128$, depth $836 \mathrm{~m}$, lat. $35^{\circ} 57,0^{\prime} \mathrm{N}$, long. $07^{\circ} 00,1^{\prime} \mathrm{W}$ (one male carapace); Station G 129 , depth $1166 \mathrm{~m}$, lat. $35^{\circ} 50,2^{\prime} \mathrm{N}$, long. $07^{\circ} 15,7^{\prime} \mathrm{W}$ (one male valve).

Dimensions. Length males $0.63-0.66 \mathrm{~mm}$, height males $0.30-0.31 \mathrm{~mm}$; length females $0.63-0.66 \mathrm{~mm}$, height females $0.30-0.32 \mathrm{~mm}$.

\section{Loculicytheretta aff. L. pavonia (Brady, 1866)}

$$
\text { (Pl. 1, figs. 2, 5, 6) }
$$

1978 Loculicytheretta aff. pavonia; Bismuth, Keij, Oertli \& Szczechura: 233, pl. 1, figs. 12-22.

Remarks. This form differs from $L$. pavonia mainly in having four rather than three Ioculi, of which the anterior one, according to Bismuth et al. (1978), is sometimes more poorly developed than the other three. Loculicytheretta aff. L. pavonia was reported from Nigeria (Pleistocene and Recent), Senegal and Sierra Leone (both Recent). The new locality, off the coast of Guinea, lies in the same area: Meteor station $16418-2$, depth $133 \mathrm{~m}$, lat. $09^{\circ} 53,2^{\prime} \mathrm{N}$, long. $16^{\circ} 38,3^{\prime} \mathrm{W}$. Dimensions. Length of figured specimen $0.60 \mathrm{~mm}$, height $0.29 \mathrm{~mm}$.

Loculicytheretta morkhoveni sp. nov.

(Pl. 1, figs. 4, 7-11; Pl. 2, figs. 1-11)

1962/63 Loculicytheretta sp.; van Morkhoven: Pt. 1, 93, Pt. 2, 133, fig. 201.

1978 Loculicytheretta n. sp. van Morkhoven; Bismuth, Keij, Oertli \& Szczechura: 234, 245, pl. 2, fig. 23.
Derivation of name. After F.P.C.M. van Morkhoven; who reported this species for the first time.

Diagnosis. A Loculicytheretta species of which the females have six clearly developed loculi in each valve; three longitudinal ridges are present, the ventral one less pronounced; surface coarsely pitted.

Holotype. A female right valve, no. K 7530 , illustrated in Pl. 1, figs. 8, 10 and Pl. 2, figs. 2, 4, 10. [Paratypes: One male carapace, one female carapace, two male valves, two female valves, two juvenile valves, nos. $\mathrm{K}$ 7531-K7538].

Material. In three samples, a total of 79 valves and carapaces was found.

Type locality. Beach of Bakau, Cape St. Mary, Republic of The Gambia, lat. $13^{\circ} 28^{\prime} \mathrm{N}$, long. $16^{\circ} 47^{\prime} \mathrm{W}$. (Sub)recent; no living individuals were collected.

Description. Carapace elongate in lateral outline, dorsal and ventral lines almost straight. Anterior end evenly rounded, posterior end obliquely truncate.

Three longitudinal ridges are present, dorsal one shortest, medium and ventral ones connected near the posterior margin. This feature is especially distinct in males and juveniles, less so in females. Surface covered with numerous pits, arranged in a characteristic pattern of rows. Intensity of the pitting, particularly of the females, variable, as nearly smooth to reticulate surfaces were found.

Soft parts unknown.

Distribution. The species was found in three samples from West African beaches; Cap Skirring (Senegal), Bakau and Fajara (both Cape St. Mary, The Gambia). One carapace was found in a sample from deeper water off Guinea; Van Morkhoven's report (1962/63) is also from The Gambia. Possibly also Morocco (Pliocene, see Remarks).

Remarks. The females with their characteristic loculi cannot be mistaken for any other Recent ostracod species. Males of $L$. aff. $L$. pavonia seem to be quite similar, according to the illustrations in Bismuth et al. (1978). Unfortunately, we have no males of this form in our collection. Males of $L$. pavonia have a different ornamentation: the pitting is much finer (especially along the posterodorsal margin), and the ventral ridge is clearly threefold.

\section{Explanation of Plate 2}

Figs. 1-11. Loculicytheretta morkhoveni sp. nov., fig. 1, 9 LV, K 7535, lateral view ( $\times 90)$; fig. 2 , $q$ RV, K 7530 (Holotype), lateral view ( $\times 90)$; fig. 3, Q LV, K 7535, internal view ( $\times 90)$; fig. 4, 9 RV, K 7530 (Holotype), internal view ( $\times 90)$; fig. 5, O' LV, K 7533, internal view $(\times 90)$; fig. 6, $q$ RV, K 7536, ventral view ( $\times 95)$; fig. 7 , ㅇ LV, K 7535, ventral view ( $\times 95)$, fig. 8, $\sigma^{7} \mathrm{LV}, \mathrm{K} 7533$, lateral view $(\times 90)$; fig. 9, $\sigma^{7}$ car., K 7531, right lateral view $(\times 90)$; fig. 10, ㅇ RV, K 7530 (Holotype), hinge structure $(\times 175)$; fig. 11, + LV, K 7535, hinge structure $(\times 175)$. All specimens from the type locality. 

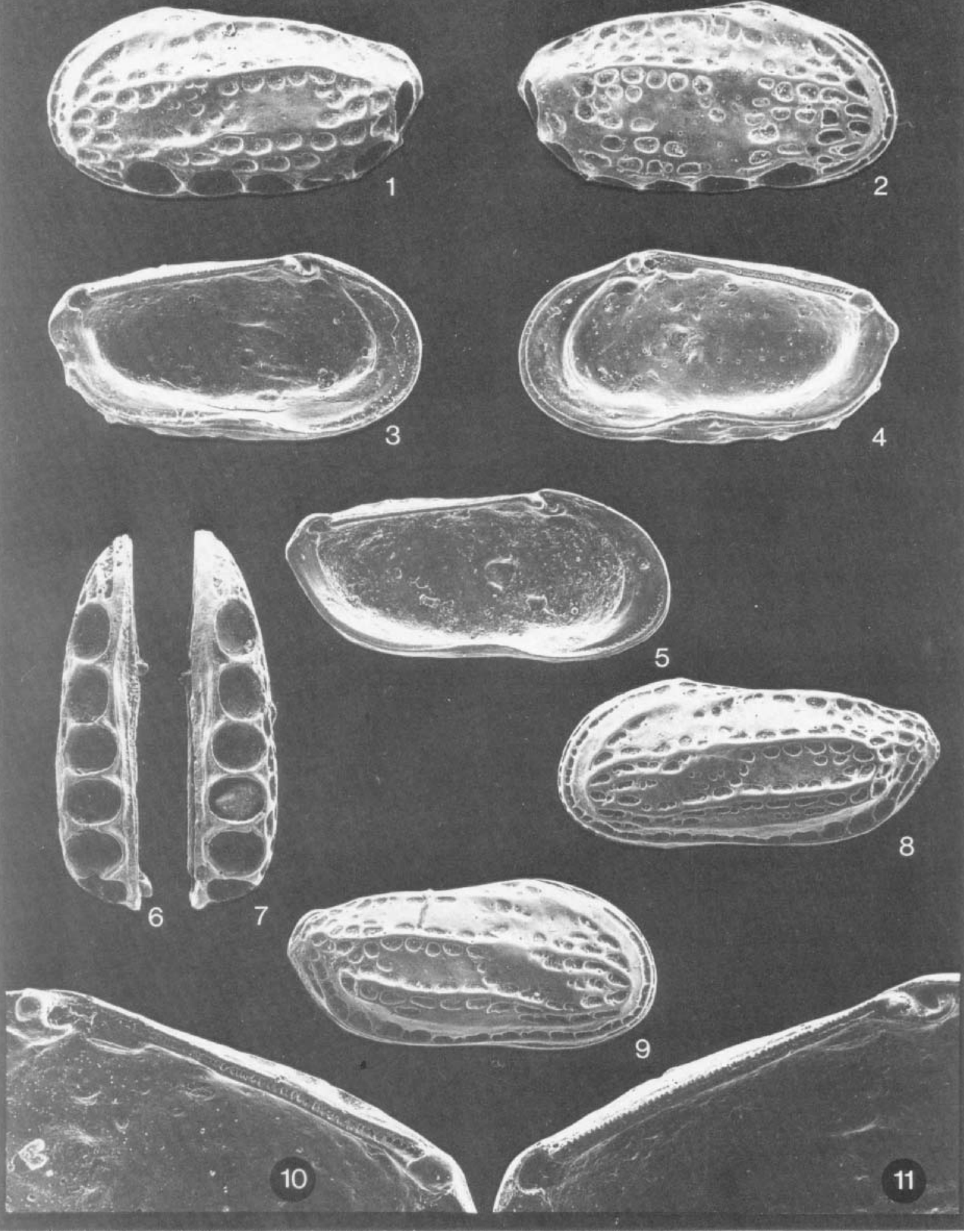
Oertli, in Bismuth et al. (1978, Addendum 3) mentions material that was sent to him by $\mathrm{P}$. Carbonel (University of Bordeaux I) from Upper Miocene and Lower Pliocene sections of Morocco. Three species appeared to be present; two of these ( $L . \mathrm{sp}, 1$ and $L$. sp. 2) were later described by Carbonel \& Colin (1982) who assigned them an Early Pliocene and Pliocene age. The third species, represented by one badly preserved specimen only, probably also from the Pliocene, was, according to Oertli (op. cit.), most likely $L$. n. sp. van Morkhoven, 1963. If that identification is correct, it implies a considerable extension of the range and distribution of the new species.

Dimensions. Length males $0.63-0.67 \mathrm{~mm}$, height males $0.30-0.33 \mathrm{~mm}$; length females $0.65-0.71 \mathrm{~mm}$, height females $0.33-0.36 \mathrm{~mm}$.

\section{ACKNOWLEDGEMENTS}

The author wishes to thank the D.F.G. (Deutsche Forschungsgemeinschaft) for giving him the opportunity to participate in "Meteor" cruise no. 65 (Geotropex '83). For my participation in the Cornide ' 82 cruise, I am indebted to the Istituto Jaime Almeria, Barcelona. All persons involved, as well as the crews of these ships, are thanked. A great number of friends and colleagues are acknowledged for their help and support in various ways. S.E.M. pictures were taken in cooperation with the Werkgroep Electronenmicroscopie of the University of Amsterdam.

Manuscript received September 1985

Revised manuscript accepted December 1985

\section{REFERENCES}

Athersuch, J. 1979. The ecology and distribution of the littoral ostracods of Cyprus. Journ. Nat. Hist., London, 13, 135-160, 17 figs.

Athersuch, J. \& Bonaduce, G. 1976. Loculicytheretta pavonia (Brady). Pubbl. Staz. Zool. Napoli, 40, 349-364, 3 pls. Barbeito-Gonzalez, P. J. 1971. Die Ostracoden des Küstenbereiches von Naxos (Griechenland) und ihre Lebensbereiche. Mitt. Haamburg Zool. Mus. Inst., 67, 255-326, 47 pls.

Benson, R. H. 1972. Ostracodes as indicators of threshold depth in the Mediterranean during the Pliocene. In Stanley, D. J. (Ed.), The Mediterranean Sea, 63-73. Dowden, Hutchinson \& Ross, Stroudsburg, $\mathrm{Pa}$.

Benson, R. H. 1976. Changes in the Ostracodes of the Mediterranean with the Messinean salinity Crisis. Paleo., Paleo., Paleo., Amsterdam, 20, 147-170, 2 figs.

Benson, R. H. \& Sylvester-Bradley, P. C. 1971. Deep Sea Ostracodes and the transformation of ocean to sea in the Tethys. In Oertli, H. J. (Ed.), Paléoécologie des Ostracodes, 63-92. Bull. Centre Rech. Pau-S.N.P.A., 5 suppl., 63-91, $1 \mathrm{pl}$.
Bismuth, H., Keij, A. J., Oertli, H. J. \& Szczechura, J. 1978. The genus Loculicytheretta (Ostracoda). Bull. Centre Rech. Pau - S.N.P.A., 2(2), 227-263, 6 pls.

Bonaduce, G. \& Masoli, N. 1968. Marine Ostracoda of Tunisia. Pubbl. Staz. Zool. Napoli, 36, 458-470, 2 pls.

Bonaduce, G. \& Pugliese, N. 1975. Ostracoda from Libya. Pubbl. Staz. Zool. Napoli, 39, 128-135, 2 pls.

Brady, G. S. 1866 . On new or imperfectly known species of marine Ostracoda. Trans. Zool. Soc. London, 5, 359-393, pls. 57-62.

Carbonel, P. \& Colin, J. P. 1982. New observations on the morphology of loculate Cenozoic Ostracoda. In Bate, R. H., Robinson, E. \& Sheppard, L. M. (Eds.), Fossil and Recent Ostracoda, 439-452. Ellis Horwood, Chichester for the British Micropaleontological Society, London.

Doruk, N. 1974. On Loculicytheretta pavonia (Brady). Stereo-Atlas of Ostracod Shells, London, 1, 4, 237-244.

Harten, D. van 1984. A model of estuarine circulation in the Pliocene Mediterranean based on new ostracod evidence, Nature, London etc., 312, 359-361, 3 figs.

Keen, M. C. 1972. Recent ostracod assemblages from the coast and shelf of Sierra Leone. Actes 4 ème Coll. Afric. Micropal., Abidjan, 195-205, 6 figs.

McKenzie, K. G. 1971. Paleozoogeography of freshwater Ostracoda. In Oertli, H. J. (Ed.), Paléoécologie des Ostracodes. Bull. Centre Rech. Pau - S.N.P.A., 5 suppl., 207-237.

McKenzie, K. G. 1973. The Biogeography of some Cenozoic Ostracoda. In Hughes, N. F. (Ed.), Organisms and Continents through Time, 137-153. Spec. Paper Palaeont., London, 12

Morkhoven, F. P. C. M. van 1962. Post - Paleozoic Ostracoda, vol. 1, 204 pp., 79 figs. Elsevier, Amsterdam.

Morkhoven, F. P. C. M. van 1963. Post - Paleozoic Ostracoda, vol. 2, 478 pp., 763 figs. Elsevier, Amsterdam.

Müller, G. W. 1912. Ostracoda. In: Das Tierreich. Eine Zusammenstellung und Kennzeichnung der rezenten Tierformen. Königl. Preuss. Akad. Wiss. Berlin. Autorisierter Neudruck 1966, Weinheim.

Oertli, H. J. 1976. The evolution of Loculicytheretta in the Eocene. Abh. Verh. Naturwiss. Ver. Hamburg, NF 18/19, suppl., 153-160, 1 pl.

Peypouquet, J. P. 1977. Les Ostracodes, indicateurs paléoclimatiques et paléogéograhiques du Quaternaire terminal (Holocène) sur le plateau continental Sénégalais. In Löffler, H. \& Danielopol, D. (Eds.), Aspects of ecology and zoogeography of recent and fossil ostracoda. 369-394. Junk Publishers, The Hague.

Puri, H. S., Bonaduce, G. \& Gervasio, A. M. 1969. Distribution of Ostracoda in the Mediterranean. In Neale, J. W. (Ed.), The Taxonomy, Morphology and Ecology of Recent Ostracoda, 356-411. Oliver \& Boyd, Edinburgh.

Ruggieri, G. 1954. Iconografia degli Ostracodi marini del Pliocene e del Pleistocene Italiana. Pte 2a. Atti Soc. Ital. Sci. nat, Milano, 93, 561-575, figs. 17-41.

Yassini, I. 1979a. The littoral system Ostracodes from the Bay of Bou - Ismail, Algiers, Algeria. Rev. Esp. Micropal., Madrid, 11, 3, 353-416. 12 pls.

Yassini, I. 1979b. Repartition des Ostracodes dans une serie marine régressive d'âge Pliocène dans la région d'Alger, Algérie. Rev. Micropaléont., Paris, 22, 89-124, 11 pls.

Wouters, K. 1973. Quelques Ostracodes du Tyrrhénien de Monastir (Tunisie). Ann. Mines Géol., Tunis, 26, 279-399, 3 pls. 